Mariusz Marczak

Jagiellonian University

mariusz.marczak@uj.edu.pl

\title{
Concordancer-Enhanced Reflection in Telecollaborative Translation Projects at University Level
}

[An individual] [...] has to see on his own behalf and in his own way the relations between means and methods employed and results achieved. Nobody else can see for him, and he can't see just by being "told."

[Dewey, 2008: 57]

\section{The rationale for the use of telecollaboration in translator education}

For a number of reasons, contemporary translator education needs to shift towards the implementation of telecollaboration work modes, involving the use of Computer Assisted Translation (CAT) tools [Mrochen, 2014].

Firstly, over the past few years the global translation market has continued to experience sustained growth, which by different estimates occurs at the annual rate ranging from 4.2 percent $^{1}$, through 5-7 percent [Boucaud, 2005], through 6.2 percent [DePalma et al., 2014], up to 10 percent [Pym, 2016].

Secondly, there is a demand for cost- and time-effective services [Gil, Pym, 2006; Choudhury, McConnell, 2013], which requires flexibility and the use of teamwork [DGT, 2016] as well as effective collaboration

Average value; U.S. Bureau of Statistics reports that the translation industry is expected to grow by $42 \%$ between $2010-2020$. 
between the parties involved in the translation process [Choudhury, McConnell, 2013]. What is more, it stimulates the automation of translation [TAUS, 2013], which in turn renders the ability to use CAT tools one of the most sought-after qualities on the translation job market [Bondarenko, 2015]. All that finds reflection - and institutional endorsement for the years to come - in the Directorate-General for Translation's Strategic Plan 2016-2020, whose authors postulate that "The future tools should allow DGT translators [who provide translation services in and out of the European Union's twenty-four official languages] to work equally efficiently in their office or telework and collaborate on translation projects, in real-time or via standardised information exchanges, between themselves, with freelance contractors and with translators from other EU institutions" [DGT, 2016: 13].

Thirdly, in the wake of intensified calls for the adaptation of Information and Communication Technology (ICT) for educational purposes by scholars such as Prensky [2001, 2012] or Tapscott [2008], the 21st century has seen ICT-aided instruction become a well-established element of instructional practices. What is more, in Zappa's [2012] view, technology-enhanced education will continue to develop at least until the year 2040, offering new affordances with regard the technologies utilised as well as the newly-emerging learning/teaching contexts, work modes and assessment methods.

\section{Telecollaboration as a teaching/learning mode}

\subsection{General overview}

Telecollaboration is a Web-enhanced form of collaborative learning, which reflects the basic tenets of the social-constructivist approach to education, dating back to the 1970s and the early 1980s and reverberating with the ideas of educational psychologist Vygotsky [1978, 1994] and American philosopher and educational reformer Dewey [1916, 1938/1974].

As Reinsmith [1992] demonstrates, collaborative learning dispels the paradigm of teaching as the process of knowledge transmission and questions the teacher's role as that of the transmitter or disseminator of knowledge, which places the parties involved in the process - not the content to be disseminated - at the core of the learning experience. This 
inertness of both teachers and learners transforms learning into a depersonalised procedure which to a large extent consists in imitation and does not command active learner involvement.

Instead, collaborative pedagogy aims to empower the learner and perceives learning as a social experience, whereby knowledge is actively explored and constructed through teacher-student and student-student interaction. It is important to emphasise both kinds of interaction involved in social-constructivist learning, as they are supposed to be complementary towards each other and one by no means is to exclude the other. Vygotsky [1978] made it very clear when elucidating the principles of his Zone of Proximal Development (ZPD) theory, through which he underlined that individuals - children, originally - would be capable of advancing to a higher developmental level, referred to as the expert stage, if while working on their learning tasks they were assisted by others - adults, in that case. In this way they would be able to perform tasks which they would fail to complete, if they were left to their own devices and needed to operate single-handedly. Vygotsky [1978] envisaged that the Zone of Proximal Development referred to what learners could do with the aid of an adult, who - by setting an example - would foster the child's ability to ultimately complete certain tasks successfully without assistance.

Crucial to this kind of development was the concept of adult support, which corresponds to what Wood, Bruner and Ross [1976] labelled as scaffolding. It is the support that an inexperienced, novice learner may obtain from a more experienced adult. Scaffolding is therefore a concept which refers to the facilitative role interaction, the kind of interaction that a child, or an inexperienced learner, engages in with an adult, or another, more experienced person.

What the above-cited vision of learning clearly implies is that scaffolding does not need to be provided by the teacher only, as the role of a more experienced adult from the Vygotskyian model of the ZPD may also be performed by a more knowledgeable - or more experienced co-learner. In conclusion, social-constructivist learning relies on teacher- and peer-support, which transforms the teacher from what Reinsmith [1992] calls a transmitter or disseminator of knowledge into a facilitator or guide. Consequently, as learning becomes inductive, rather than deductive, and instruction is far less direct, the teacher needs to 
relinquish at least some of the power and control that he/she normally assumes in the classroom in order to facilitate the learning process. At the same time, learners need to realise that their role is to participate in learning in a collaborative manner, i.e. to try and contribute to the well-being of the entire group, or rather project team in this case, which echoes Dewey's [1916] philosophy of democratic education.

Collaboration has been strongly supported as an effective learning mode throughout the 20th and 21 st century on several grounds. It has been credited with the power to base learning on experience and reflection, which has been advocated by educational psychologists Rogers [1983] and Kolb [1984]. While Rogers [1983] emphasised behavioural and affective change in learners, Kolb [1984] underlined the role of reflection and readiness to experiment and adapt in learning.

Murphey and Jacobs [2000] as well as Dooly [2008] observed that collaboration promotes learner autonomy and creates in students a sense of responsibility for their own learning.

Beckman [1990] supported the idea that collaborative work modes result in greater retention of knowledge, while Van Lier [1996] and Dooly [2008] drew attention to the fact that teamwork generates a synergy effect in that it fosters the acquisition of an amount of knowledge which goes beyond the sum of the knowledge already possessed by all the learners involved in the collaborative experience.

\subsection{Potential issues in collaborative settings}

As telecollaboration requires a re-think of the traditional teacher-learner roles, it is likely to constitute a number of challenges for both teachers and learners. To begin with, teachers may find it difficult to relinquish control and start playing a somewhat passive role, which they may view as unnatural [Hein, 2002]. They may also occasionally feel frustrated by the fact that their students engage in discussions of topics in which teachers have little or no expertise [ibid.].

What is more, even if the teacher overcomes the aforementioned issues, they may not be credible in their role as facilitators at university, where they are credit-givers and evaluators at the same time. The most optimal solution to the problem would be teachers' attempt to attend in their actions equally to both ends of the continuum spanning between the role of a hard teacher and a soft teacher [Elbow, 1986]. 
As Reinsmith [1992] observes, the learner-centeredness of collaborative learning also has important implications for the learners themselves, especially in the context of university studies, which are inherently associated with the ideals of individualism and competition. It is in that context that learners need to suddenly set aside their competitive inclinations and replace them with a more collaborative mindset, which would permit them to provide peer support to others.

One must also be cognisant of the fact that collaborative learning is not suitable for all learners, irrespective of their orientation towards education, their source of motivation and the learning strategies which they employ. Entwistle [1988] proposed a classification of university student orientations, including three major categories of students. The first category comprises students with a personal orientation, intrinsically motivated by the need to self-develop and willing to involve in tasks which they view as personally rewarding. The second category covers students with a reproductive orientation, an interest in developing vocational skills, extrinsically motivated by the desire to obtain vocational qualifications and eagerly engaging in syllabus-bound tasks, which they complete by rote learning. The third category contains students with an orientation towards achievement, who approach university studies as an opportunity to face challenges and excel, and who are motivated by achievement/success in the university game - so to speak - which they play in order to win.

All the three categories of students are likely to fit into the social-constructivist learning model with varying degrees of suitability, depending e.g. on their perception of the teacher. Thus, students with a personal orientation seem to be suitable candidates for learner-centred work, as they are likely to accept the teacher as a guide who is to help them self-realise, given that they view the collaborative learning experience as an opportunity for personal development, and they have a set of clear personal objectives to meet, which is more likely to be the case at post-graduate, rather than under-graduate level. Those with a reproductive orientation will be more likely to treat the teacher from the behaviouristic perspective, i.e. as a dog trainer - or a drill-master [Reinsmith, 1992] - rather than a facilitator or guide, which gives them limited predispositions for collaborative work. Finally, students with an achieving orientation may accept the rules of telecollaboration and feel motivated to overcome the 
challenges it involves in order to win the game, provided they perceive the telework in question as their game, i.e. one where the final success will be congruent with their own vision of achievement.

The learner profile which seems to predispose a student best for the kind of inductive, learner-centred work which collaboration entails corresponds to Knowles' [1980, 1984] model of adult learning, which presumes the learner to be: (i) self-directed; (ii) equipped with a reservoir of experiences, which is likely to facilitate the learning process; (iii) ready to learn and able to diagnose their own learning needs in relation to their personal lives; (iv) oriented towards learning, i.e. performance-centred and eager to apply the knowledge and skills which they possess in order to solve practical tasks and ultimately increase their competence(s); (v) motivated intrinsically, e.g. learning in order to satisfy their need for self-esteem; and (vi) aware of the reasons beyond their learning needs, so that they are fully aware of why it is that they need to learn a specific thing.

In the light of the above, it may be stated that student-centred, collaborative work, facilitated by the teacher, requires the student not only to possess experience which could foster collaboration and self-development but also to display a certain level of maturity and personal as well as metacognitive self-awareness. These are likely to be the characteristics of students on post-graduate level programmes, rather than those enrolled on under-graduate courses.

\subsection{Telecollaboration as an extension of collaborative learning}

O'Dowd [2010] and Dooly and O'Dowd [2012] define telecollaboration as the utilisation of Web-based communication tools for the purpose of teamwork consisting in the completion of project tasks. In other words, it may be perceived as an extended form of collaboration, which is enhanced by the use of Information and Communication Technology. Having said that, it is desirable to examine how the introduction of modern technologies and the resulting shift from collaboration to telecollaboration affect the educational affordances of the solution.

The very fact that Computer-Mediated Communication (CMC) permits forms of telework is already an advantage in itself, as it frees learners from the constraints of the classroom and enables them to work more flexibly and collaborate from the place and at the time of convenience. It 
is for that reason - inter alia - that Kukulska-Hulme et al. [2009] deem telecollaboration a portable, individualised, unobtrusive, adaptable and useful learning mode.

In telecollaboration, team members are likely to be recruited from a spectrum of locations, which in Belz's [2003] view, constitutes another advantage of the work mode. It is so due to the fact that outsiders are likely to enrich group discussions and the decision-taking or negotiation processes through a range of diverse views and ideas.

The communication practised as part of telecollaborative project work can involve both synchronous and asynchronous formats. The former refers to interaction in real time, which may be performed by means of videoconferencing services, online chat, or Voice-Over-Internet-Protocol (VOIP) solutions, while the latter - by contrast - involves the use of Web-based tools which permit communication with a delay, i.e. in contexts where the sender of a message needs to wait for a period of time before they receive a reply from the recipient, e.g. email, Web forums, blogs or mailing lists.

While the most obvious potential asset of synchronous communication is its instantaneousness, asynchronous communication has more to offer. As Dooly [2008] observes, research indicates that telecollaboration democratises teamwork, as it gives voice to those learners who in conventional learning settings tend to be intimidated and inhibited by other, stronger learners. Thus it is the asynchronous communication mode that is likely to encourage weaker learners to eagerly contribute to communicative exchanges in a team, as they have more time to think through their contribution.

Dooly [2008] additionally raises the point that telecollaboration is likely to prepare learners to use ICT tools in a productive fashion, which may help them prepare effectively for their professional career after graduation. 


\section{Collaborative work modes in translator education}

\subsection{Collaboration in translator education literature}

Although research into the use of telecollaboration in translator education is scarce [Massey, 2015] $]^{2}$, the implementation of collaboration work modes in translator education is not a new concept, and it has been advocated by a number of scholars, including Kiraly [2000] and GonzálesDavies [2017]. Kiraly [2000] in his A Social Constructivist Approach to Translator Education made an attempt to persuade translator educators to rethink their teaching practices and consider options other than the conventional teacher-centred scenario based on knowledge transmission. He observed that the social-constructivist learning paradigm, promoted by Dewey [1938/1974; 2008] and Vygotsky [1994], appealed to him not only as a pedagogical alternative to the practices of translator educators at the turn of the new millennium, but also as a learning mode corresponding to the professional practices of translators and thus apparently promising to foster the development of what he termed as translator competence. He made an observation that translation - similarly to collaboration - also requires interaction, not only with text but also with a wide range of communities of practice, and thus it must be perceived with regard to the social and cognitive processes and intercultural communication which it involves.

Kiraly [2000] underlined the fact that the dramatic change to the nature of the translator's work, e.g. the multiple roles that he/she may need to adopt, the increased pace of translation, correction and teamwork, was a consequence of the introduction of Information and Communication Technology to translation. In effect, to handle the challenges of learning a rapidly growing set of new electronic tools, computer-mediated intercultural communication and new work modes under the constraint of time, translators need to act creatively and flexibly, which - in his view - students of translation could be best taught via collaboration. He has also reiterated his endorsement for collaborative learning in his latest publications, where he promotes emergentist, situated and action-driven learning, which he expects to lead to the emergence of enacted, context-based, dynamic and situated instantiation of translator competence,

2 Gary Massey (July 3rd, 2015): personal communication, Kraków. 
perceived as knowing, rather than knowledge [Kiraly, 2015; Kiraly, Hofman, 2016].

In A Collaborative Pedagogy for Translation, Gonzáles-Davies [2017] offers practical guidelines for those who would like to utilise collaboration with university students on translation programmes. She sets out by offering a theoretical overview of the most important tenets of social-constructivist learning. Afterwards, on the basis of her own experience as a translator educator, she introduces the reader to selected principles informing syllabus design for collaboration-enhanced courses as well as presents examples of particular short activities, longer problem-focused tasks and fully-fledged authentic translation projects, performed for external clients.

One can see that collaboration has already occupied its own place in the field of translator education, and it has more advocates amongst theorists and practitioners, e.g. Pym [2011] or Klimkowski [2015], however differently they may perceive constructivist learning, its procedures and merits. Consequently, it seems only natural to attempt to implement Web-enhanced collaborative work modes, i.e. telecollaboration, as yet another option for translator educators; the more that it seems to be an adequate response of the academia towards the realities of the contemporary translation market, where Web-based technologies are being utilised on a considerably larger scale than it was the case back in the year 2000, when Kiraly [2000] recommended social-constructivist learning as a desirable pedagogical solution.

\subsection{Telecollaboration in translator education: learning gains}

The harnessing of telecollaboration in translator education may bring about a number of undeniable learning gains which derive from the potential of Web-based learning at large.

As Lankshear and Knobel [2006] maintain, by involving students in online learning scenarios, one can further not only the development of their linguistic and communication skills, but also ensure the development of a range of operational, cultural and critical literacies. They view operational literacy as procedural knowledge, the skills one needs to work online: use Web-based tools CMC tools, perform effective Web searching, share resources and information as well as engage in multitasking, i.e. the simultaneous performance of a number of tasks. Cultural 
literacy, for a change, embraces declarative knowledge which refers to the general principles of communication and norms guiding communication in particular contexts, the knowledge of the explicit and implicit rules of online communication, i.e. the Netiquette, as well as issues relating to digital content ownership, i.e. copyright. Critical literacy has an emotive - or affective - character, as it regards awareness of more subtle issues inherent in online communication, such as the power relations promoted by the Web-based tools used in specific communicative situations. The present author would extend this literacy to critical, creative and analytical thinking skills.

Davidson [2012] complements the list with a set of other literacies, which seem to be indispensable in the 21 st century, including: collaboration, critical consumption of information, learning, unlearning, and relearning. On closer inspection, one will observe that at least to some extent Davidson's [2012] literacies dovetail with those that Herk [2015] refers to as soft skills, i.e. universal, transferrable skills which enhance an individual's employability status on the modern day job market, irrespective of the kind of employment one seeks.

Various classifications and more or less extensive lists of soft skills have been proposed to date by academic and professional organisations [Szulc. n.d.] as well as researchers [Bartel, 2011; Han, n.d.; Mathias, 2013]. Although a thorough discussion of the lists is far beyond the scope of this paper; one can observe that the lists commonly include the following: communication skills, new media skills, teamwork, interpersonal skills, cultural awareness, flexibility, strategic planning, selforganisation, creativity, analytical and critical thinking skills and leadership skills. Telecollaboration has the potential to foster the development of all of these skills, which is an asset in professional education.

As research results [NACE 2016] reveal, soft skills are at the core of the employee profile which contemporary employers find the most desirable, and they may even be prioritised over those hard skills which correspond to a particular professional context. It is illustrated by The National Association of Colleges and Employers' (NACE) list of the key qualities sought after on the USA job market, where the top positions are occupied by the following transversal employability skills: (i) the ability to work in a team structure; (ii) verbal communication skills; (iii) decision taking and problem solving; (iv) information processing; (v) 
planning, organising and prioritising work; and (vi) analysing quantitative data.

Despite the potential learning gains that telecollaboration seems to offer, one must not take it for granted that the aforementioned literacies and skills will automatically develop in students involved in telecollaboration projects. As O'Dowd [2016] $]^{3}$ observed, teachers must not assume learning happens simply because opportunities are created for it, especially in telecollaboration. This is confirmed, albeit somewhat implicitly, by Dooly and O'Dowd's [2012] definition of telecollaboration, in which they bring to the fore the fact that apart from the use of Webbased communication tools for the purpose of collaborative interaction in social contexts, telecollaboration is also supposed to involve critical reflection. Consequently, students will benefit from telecollaboration not through mere participation, but rather by dint of reflection on experience. It is reflection that is likely to raise students' metacognitive awareness, as a result of which, they may not only realise what literacies they are working on and what they can do in order to develop them, but also to diagnose their strengths and weaknesses, with a view to setting appropriate learning goals which they would individually strive to achieve.

Since Guth and Helm [2012] additionally highlight the need for scaffolding from the teacher in telecollaboration projects, it is reasonable to suggest that the scaffolding is not limited to assisting students with task completion only, but it is extended to facilitating reflection on the learning affordances of a given telecollaboration project, the nature of students' own learning in the course of the project, the competences and skills being developed as well as those to be improved or developed in the future.

\section{Eliciting reflection on experience in telecollaboration projects}

\subsection{Selected means of elicited reflection}

In the telecollaboration projects, administered by the present author with students on Translation Studies programmes at university, he has used a number of means by which he attempted to elicit and direct reflection on the telecollaborative experience. Primarily, they were survey-type

3 Robert O’Dowd (April 22nd, 2016): personal communication, Dublin. 
questions, both open- and close-ended, which were supposed to elicit students' general thoughts on the benefits of telecollaboration as learning mode, the telework performed as well as the competences and particular skills they had had a chance to develop.

The first category of questions aimed to raise students' metacognitive - but potentially, also meta-affective - awareness with regard to telecollaborative learning. For example, general questions required students to reflect on telecollaboration as a useful work mode in translator education, so that they could consider their own learning processes involved in the performance of the telework-based project which they had completed from the perspective of their professional needs. Openended as the question was, it nevertheless required a justified response, which was to persuade students to reach beyond the Yes/No dichotomy and make them realise what potential learning gains they, or their colleagues, may have possibly derived from the learning experience.

The responses obtained revolved around the development of instrumental skills, e.g. the ability to use specific CMC or CAT tools, but also soft skills, including time management skills, and affective skills, e.g. controlling one's emotions or affective, and meta-affective awareness, i.e. the knowledge of self ${ }^{4}$.

More personalised questions were also asked in order to focus students' attention on their individual ability to perform telecollaborative assignments in the light of the project work they had already performed. By asking such questions, the present author stimulated students to consider their strengths and weaknesses as well as factors potentially inhibiting their contribution to Web-enhanced teamwork.

Another category of questions aimed to direct students' reflection towards the in-project performance of their colleagues, so that they could benefit from the social aspect of telecollaboration. For instance, students would be asked whether they had reflected on their colleagues' ability to telecollaborate. By doing so, students were supposed to retrospectively analyse their colleagues' performance, so that they themselves could benefit from examples of successful telework as well as reflect on their colleagues' failures, also by relating their observations to their own work. The advantage of this kind of reflection lies in the fact that

$4 \quad$ See Marczak and Krajka [2016] for details. 
students are likely to find it easier to make observations pertaining to the performance of others. At the same time, they are likely to feel the natural need to compare their findings with their own telecollaborative experience.

Close-ended questions contained a list of specific skills, including soft skills, that students believed to have had an opportunity to develop in the course of the project work. Since students' responses were limited to the selection of particular response options in this case, the major purpose in asking such questions was to make students aware of the extent to which telecollaboration, at least potentially, permitted them to tackle a given set of skills, and also which skills had been left out. As a result, students were supposed to realise which literacies or skills needed further attention in the future.

Finally, students were also asked to articulate their viewpoints with regard to the nature/nurture character of reflection in telecollaboration projects, while through a close-ended question they would indicate the most effective means of eliciting reflection, in their view. To be more precise, in a general question they stated whether reflection naturally accompanied telecollaboration, or whether it needed to be elicited, whereas in a detailed question they marked which instruments, out of the range listed, lent themselves best to stimulating reflection in telework-based translation educator contexts.

Interesting responses to such questions were reported by Marczak and Krajka [2016], whose students on the one hand claimed in a vast majority that telecollaboration naturally evoked reflection, while on the other hand, when faced with a choice of specific means of reflection, they placed natural, unelicited reflection at the very bottom of their list of preference. The findings seem to imply that, when offered a choice, students have a preference for elicited, structured reflection, perhaps due to the incidental and haphazard nature of reflection which occurs naturally. The forms of elicited reflection favoured by students were: survey-type questions, self-reflection tasks and student-teacher discussion $^{5}$. The only form of elicited reflection that a very small proportion of students selected were teacher-student interviews; possibly because they would take a considerable amount of time to administer, and they would

See Marczak and Krajka [2016] for details. 
involve a situation where students' self-expression could be inhibited by the immediate presence of the teacher.

\subsection{Concordancer-enhanced reflection: towards process-oriented analysis}

A major disadvantage of the forms of elicited reflection discussed so far is their declarative and fragmentary nature, as they are based on students' declarations of what allegedly happened in the course of the telecollaboration project. Informative as such declarations may be - at least to a certain degree - they cause concerns about the reliability of the data obtained due to their anecdotal nature, the imperfections of human recall, and difficulty in validating the truthfulness of students' claims, unless one inspects the actual project work performed.

A possible means of this kind of inspection is the use of a concordancer, which according to the Longman Dictionary of Language Teaching and Applied Linguistics, is:

[...] software that searches for words or phrases in a corpus and displays the selected item or items in a list together with their surrounding context. Concordancers enable the uses of words to be displayed together with contexts of use $[\ldots]$ and are used in discourse analysis and other forms of language analysis. They are also sometimes used by teachers to provide students with examples of authentic language use [...] [Richards, Schmidt, 2013: 113].

Interestingly enough, concordancers are not strange to translators, who utilise online concordancing services for reference purposes. In addition, concordancers constitute one of the functionalities offered by Computer Assisted Translation tools ${ }^{6}$.

As concordancers permit the analysis of single utterances and selected fragments of communicative exchanges, they can assist both translator educators and students in gaining insight into the actual processes and actions performed in the course of a telecollaboration project, which may permit them to examine in far greater detail the kinds of learning

6 For a detailed discussion of the use of concordancers as a functionality of CAT tools and the implementation of concordancing in Computer Assisted Translation, see Zanettin [2015] and Quah [2006]. 
opportunities that arise, the skills being used and even the progress that students make, or lack of it.

In other words, thanks to concordancers, teachers and students can tap into the very telework and no longer need to rely on recall and a set of after-thoughts and selective reflections, which by definition may have already been distorted by students' individual interpretations of events. What needs to be prepared is a corpus of project communication, i.e. a record of all the instances of communication that occurred as part of the telecollaboration performed, which in the case of Web-based teamwork is easily available, as online communicators either automatically save communication data, or they permit the user to save the data in electronic format. The more comprehensive the communication data, the more thorough the ensuing analysis.

An example of a simple and user-friendly concordancer that can be used for analysing in-project communication is textSTAT ${ }^{7}$, which generates concordances for corpora saved in MS Word (.docx), Libre Office (.odt) or plain text (.txt) formats. Once the corpus has been saved, it can be distributed to students for analysis, which can be performed individually, in pairs or groups.

To begin with, students need to run a search which will generate a list of word frequencies. In this manner, they can quickly establish with what frequency particular words were used by the telecollaboration participants. Out of the list they can select for analysis those words key words, as they are called - which they deem most relevant to their purposes. Afterwards, they can run a concordance search for the key word of their choice, which will display a list of all the sentences from within the corpus containing the key word in question; the sentences are aligned vertically on the screen so that the key words in the sentences are displayed in a column, one instance of the key word under another. In this manner, students can scour the sentence list for contexts in which the key word was used in the course of telecollaboration. That is only a preliminary analysis, as the manner in which the sentences are displayed enables students to see only sentence fragments, rather than complete sentences. When they identify the sentences of interest to them, they can further inspect the context in each case through the

Downloadable from http://neon.niederlandistik.fu-berlin.de/en/textstat/. 
Citation functionality, which permits them to read through the complete sentence, as well as consult the preceding and following sentences for broader reference.

By identifying appropriate key words, students may analyse in-project communication, from which they may infer the kinds of activities that particular team members engaged in, their responsibilities, the tools and resources they used, or their motivations for participation in specific communicative interactions. Since online communicators, from which the corpus data originates, append text with details such as the message sender, date, time, etc., students may use the Citation functionality of textSTAT in order to examine project communication from a number of other angles. For instance, they may examine posts sent by particular team members who acted as translators, reviewers, editors, proofreaders or project managers. They may also investigate what problems the project participants faced at specific stages of the project, delineated by certain time marks, or they may examine on which days of the week project communication peaked.

\subsection{Samples of concordance-based analysis}

The following samples of concordance-based reflection on project work were collected from the communication that was mediated by a Facebook group site, created for the purpose of a telecollaboration project in LSP translation which was completed by 16 students in the first year of an MA programme in Translation and Intercultural Communication, offered by the Chair for Translation Studies and Intercultural Communication at the Jagiellonian University in Kraków, Poland.

The students worked in four teams, with specific roles ascribed to them, and under the supervision of the Project Manager, the Project Terminologist and the Project Reviewer translated selected chapters of the book entitled Healing Gardens edited by Clare Cooper Marcus, Marni Barnes and published by John Wiley and Sons. The translation project was completed in telecollaboration mode and was performed on a voluntary basis for an external client - Fundacja Ogrody Terapeutyczne from Kraków between October 2016 and January 2017.

It must be explained that the data presented in this paper have not been processed yet and will be subject to scrutiny with a view to publishing 
a thorough analysis of them as part of a larger research project; however, they are illustrative of the concept of concordancer-based reflection.

Here are excerpts ${ }^{8}$ of communication exchanges in which the Project Manager and one of the team translators were involved, appended with notes which students added in the reflection session.

Posts from PROJECT MANAGER (PM):

- "Tomorrow is the deadline for submitting another fragment of the translation" Students' note: "[PM] reminds about an expiring deadline"

- "I kindly request that all translation be corrected by 14.01. If anyone is ready before that time, please submit the text"

- Students' note: "[PM] organises/supervises the workflow"

- "Hello! I'd like to thank you all for posting the assignment XXXXYYYYY :):):)"

- Students' note: "[PM] thanks for task completion"

- "By 20.00 TOMORROW, please post terminology to the Project Terminologist. This message is addressed to Teams 1 and 2, in particular"

- Students' note: "[PM] disciplines those who have not completed the task yet"

Posts from TRANSLATOR (T):

- “ I love you, XXXXYYYYY!"

- Students' note: "[T] gratefulness, appreciation for the Project Manager"

8 The original reflections were expressed in Polish to avoid constraints caused by the need to use a non-native language. The below-cited excerpts have been translated into English with the preservation of paraverbal and verbal elements used. 
- "I created a single file with the source text of Chapter 6 (sits in the same folder as the other OCR's)"

- Students' note: "[T] informs about task completion"

What follows is a digest of students' analysis of the instances of the word prosze (Please, in English) as it was used in the project communication on Facebook. The students reported that the Project Manager used the word in:

Requests for: "help/information/attention [to a problem]/careful reading [e.g. of project announcements]/creativity/a decision to be taken/content to be posted/a reply to a message/correction", while team reviewers requested: "comments/a re-think of problems/issues to be reported/content to be posted/attention [to particular issues]".

As the students who performed the analysis summarised:

The word was most often used for requests delegating specific tasks to individuals. Usually, the request was addressed to all the project participants; less often to individuals. The word 'please' was usually used to assign tasks and draw attention to specific aspects of translation. It was very rarely used to request assistance, which means that students tended to contact one another within teams [on the general Facebook project group] and solved problems there, so that they should not make announcements on the general project forum.

\section{Conclusions}

Concordancing may benefit learners in a number of ways. First and foremost, it needs to be emphasised that, as it has been discussed, concordance-based reflection is likely to create opportunities for students to develop the three major types of literacies that telecollaboration is believed to promote: operational, cultural and critical.

At the operational level, it permits students to scrutinise team translation telework with reference to the work modes used, the tasks performed, the actions taken, the responsibilities assumed and the tools utilised. 
At the cultural level, it enables them to learn through experience what principles guide communication between the different parties involved in the translation process, including in-team communication as well as communication with the client, what norms to observe when engaging in computer-mediated communication and what copyright issues to consider when making use of online resources.

At the critical literacy level, it can not only help to raise students' awareness of power relations or emotions involved in online communication, at both verbal and non-verbal level, but also promote the development of critical and creative/analytical thinking, which reflection per se undeniably requires.

Additionally, students are given an opportunity to discover their own self, e.g. with regard to how they handle telecollaboration, including issues such as managing negative emotions or coping with the pressure of deadlines and stress.

Last but not least, such reflection enables students to look not only at their own communicative exchanges but also those of others, which permits them to extend their project experience beyond the roles which they themselves assume while telecollaborating. In effect, by learning what responsibilities, work modes, actions and problems other roles entail, they are likely to develop - or at least raise their awareness of - a wider range of literacies relevant to team translation work.

\section{References}

Bartel, J. (2011), Soft skills: what, why and how to teach them in ESL classes using Office Soft Skills. (TESL Toronto Spring Conference, Toronto, May 2011), [online] http://tesltoronto.org/wp-content/uploads/2011/05/BartelSoftSkillsSpring2011-.pdf - 18.04.2017.

Beckman, M. (1990), "Collaborative Learning: Preparation for the Workplace and Democracy", College Teaching, 38(4), 128-133.

Belz, J.A. (2003), "Linguistic Perspectives in the Development of Intercultural Competence in Telecollaboration", Language Learning \& Technology, 7(2), [online] http://ltt.msu.edu/ vol7num3/belz/ - 18.04.2017.

Bondarenko, O. (2015), “Academia expectations versus industry reality”, MultiLingual, 26(8), 31-34. 
Boucaud, F. (2005), The European Translation Industry. Facing the Future, Belgian Quality Translation Association, Brussels.

Choudhury, R., McConnell, B. (2013), Translation Technology Landscape Report, TAUS BV, DeRijp.

Davidson, C. (2012), Now You See It: How Technology and Brain Science Will Transform Schools and Business for the 21st Century, Penguin, New York. DePalma, D.A., Hegde, V., Pielmeier, H. (2014), The Language Services Market: 2014. Annual Review of the Translation, Localization, and Interpreting Services Industry, Common Sense Advisory, Cambridge, MA.

Dewey, J. (1916), Democracy and education. An Introduction to the Philosophy of Education, Macmillan, New York.

Dewey, J. (1938), Experience \& Education, Simon \& Schuster, New York.

Dewey, J. (1974), Experience \& Education, Colliers Book, New York.

Dewey, J. (2008), "Individuality and Experience", in: John Dewey. The Later Works, 1925-1953, ed. J.A. Boydston, vol. 2, Southern Illinois University Press, Carbondale.

DGT (2016), "Strategic Plan 2016-2020", [online] https://ec.europa.eu/ info/sites/info/files/strategic-plan-2016-2020-dg-epsc_may2016_en.pdf -18.04 .2017 .

Dooly, M. (2008), Telecollaborative Language Learning, Peter Lang, Bern.

Dooly, M., O'Dowd, R. (2012), Researching Online Foreign Language Interaction and Exchange: Theories, Methods and Challenges, Peter Lang, Oxford. Elbow, P. (1986), Embracing contraries: explorations in learning and teaching, Oxford University Press, New York.

Entwistle, N. (1988), Styles of Learning and Teaching. An Integrated Outline of Educational Psychology, David Fulton Publishers, London.

Gil, J.R.B., Pym, A. (2006), "Technology and translation (a pedagogical overview)", in: Pym, A., Perekrestenko A., Starink, B. (eds.), Translation Technology and its Teaching, Intercultural Studies Group, Universitat Rovira i Virgili, Tarragona.

Gonzáles-Davies, M. (2017), “A Collaborative Pedagogy for Translation”, in: Venuti, L. (ed.), Teaching Translation. Programs, Courses, Pedagogies, Routledge, London and New York.

Guth, S., Helm, F. (2012), "Developing multiliteracies in ELT through telecollaboration", ELT Journal, 66(1), 42-51.

Han, L. (no date), "Soft Skills List - 28 Skills to Working Smart", [online] https://bemycareercoach. com/soft-skills/list-soft-skills.html - 18.04.2017. 
Hein, G.E. (2002), "The Challenge of Constructivist Teaching”, in: Mirochnik, E., Sherman, D.C. (eds.) Passion and Pedagogy: Relation, Creation, and Transformation in Teaching, Peter Lang, New York, 197-214.

Herk, M. (2015), "The Skills Gap and the Seven Skill Sets that Employers Want: Building the Ideal New Hire", Committee for Economic Development, [online] https://www.ced.org/blog/entry/the-skills-gap-and-the-seven-skill-sets-that-employers-want-building-the-id - 25.07.2016.

Kiraly, D. (2000), A Social Constructivist Approach to Translator Education, Routledge, London and New York.

Kiraly, D.C. (2015), "Occasioning Translator Competence: Moving Beyond Social Constructivism Toward a Postmodern Alternative to Instructionism", Translation and Interpreting Studies, 10(1), 8-32.

Kiraly, D.C., Hoffman, S. (2016), "Towards a Postpositivist Curriculum Development Model for Translator Education”, in: Kiraly, D.C. (ed.) $V \& R$ academic. Towards authentic experiential learning in translator education, V \& R Unipress, Mainz University Press, Göttingen, 67-88.

Klimkowski, K. (2015), Towards a Shared Curriculum in Translator and Interpreter Education, Wydawnictwo Wyższej Szkoły Filologicznej we Wrocławiu, Wrocław and Washington, D.C.

Kolb, D. (1984), Experiential learning, Prentice-Hall, Englewood Cliffs, N.J.

Knowles, M.S. (1980), The modern practice of adult education: from pedagogy to andragogy, Association Press; Follet Pub. Co., Wilton, Conn. Chicago.

Knowles, M.S. (1984), Andragogy in action, Jossey-Bass, San Francisco.

Kukulska-Hulme, A., Sharples, M., Milrad, M., Arnedillo-Sanchez, I., Vavoula, G. (2009), "Innovation in Mobile Learning: A European Perspective", International Journal of Mobile and Blended Learning, 1(1), 3-35.

Lankshear, C. Knobel, M. (2006), New Literacies: Everyday Practices and Classroom Learning, Second Edition, Open University Press, Maidenhead. Marczak, M., Krajka, J. (2016), "Translator Education in the Cloud: Students' Perceptions of Telecollaborative Experiences", in: Smyrnova-Trybulska, E. (ed.), E-Learning Methodology - Implementation and Evaluation, University of Silesia - NOA, Cieszyn, 369-388.

Mathias, A.J. (2013), “Introduction to Soft Skills", [online] http://elearning.vtu. ac.in/18/enotes/SK/SK.pdf - 18.04.2017.

Mrochen, I. (2014), "Translating in the Cloud: New Digital Skills and the Open Source Movement", in: Smyrnova-Trybulska, E. (ed.), E-learning and 
Intercultural Competences Development in Different Countries, University of Silesia, Katowice-Cieszyn, 279-298.

Murphey, T. Jacobs, G.M. (2000), "Encouraging Critical Collaborative Autonomy", JALT Journal, 22, 228-244.

NACE, (2012), "Job Outlook: The Candidate Skills/Qualities Employers Want", [online] http://www.naceweb.org/s10262011/candidate_skills_employer_qualities -15.05 .2014 .

O'Dowd, R. (2010), “Online foreign language interaction: Moving from the periphery to the core of foreign language education?", Language Teaching, 44(3), 368-380.

Prensky, M. (2001), "Digital Natives, Digital Immigrants", On the Horizon, 9(5), 1-6.

Prensky, M. (2012), From Digital Natives to Digital Wisdom: Hopeful Essays for 21 st Century Education, Corwin, California.

Pym, A. (2011), “Training Translators”, in: Malmkjær, K., Windle, K. (eds.), The Oxford Handbook of Translation Studies, Oxford University Press, Oxford, 475-489.

Pym, A. (2016), Teaching what you don't know: the challenge of future technologies (unpublished), Inspirations for Translation Pedagogy. 1st CTER Congress, Kraków, 14 March 2016.

Quah, C.K. (2006), Translation and Technology, Palgrave Macmillan, Hampshire and New York.

Reinsmith, W.A. (1992), Archetypal Forms in Teaching: A Continuum, Greenwood Press, New York-West Port, Connecticut-London.

Richards, J.C., Schmidt, R.W. (2013), Longman Dictionary of Language Teaching and Applied Linguistics, Fourth Edition, Routledge, London and New York.

Rogers, C. (1983), Freedom to Learn for the 80s. Merrill Wright, New York.

Szulc, W. (no date), „Kompetencje miękkie. Jak je rozwinąć i wykorzystać na rynku pracy?", Akademickie Biuro Karier Zawodowych Uniwersytetu Łódzkiego, [online] http://www.postawnarozwoj.uni.lodz.pl/admin/zdjecia/ file/ebooks/ KOMPETENCJE\%20MI\%C4\%98KKIE.pdf - 20.01.2016.

Tapscott, D. (2008), Grown up Digital: How the Net Generation Is Changing Your World, McGraw-Hill, New York.

TAUS (2013), “TAUS Translation Technology Landscape Report”, [online] https://www.taus.net/think-tank/reports/translate-reports/taus-translationtechnology-landscape-report - 18.04.2017. 
Van Lier, L. (1996), Interaction in the language curriculum: Awareness, autonomy \& authenticity, Longman, London.

Vygotsky, L.S. (1978), Mind in Society, Harvard University Press, Cambridge, MA.

Vygotsky, L. (1994), "Extracts from Thought and Language and Mind in Society", in: Stierer B., Maybin, J. (eds.), Language, Literacy and Learning in Educational Practice, Multilingual Matters, Clevedon, 45-58.

Wood, D.J., Bruner, J.S., Ross, G. (1976), "The role of tutoring in problem solving", Journal of Child Psychiatry and Psychology, 17(2), 89-100.

Zanettin, F. (2015), "Conconrdancing”, in: Sin-wai, Ch. (ed.), The Routledge Encyclopedia of Translation Technology, London and New York, 437-449. Zappa, M. (2012), "Envisioning the future of education technology", [online] http://envisioning.io/ education/ - 25.07. 2016.

\section{STRESZCZENIE}

Refleksja wspierana konkordanserem w telekolaboracyjnych projektach tlumaczeniowych na poziomie studiów uniwersyteckich

Niniejszy artykuł porusza kwestię wykorzystania programów typu konkordanser w celu pobudzenia refleksji nad doświadczeniem w telekolaboracyjnych projektach thumaczeniowych realizowanych na poziomie studiów uniwersyteckich. Na początku przedstawiono krótkie uzasadnienie wykorzystania telekolaboracji we współczesnym przekładzie oraz w procesie kształcenia tłumaczy. Następnie opisano kolaborację i telekolaborację jako tryby pracy stosowane w procesie nauczania i uczenia się, przy czym tę drugą formę pracy potraktowano jako wspieraną komputerem formę kolaboracji. W dalszej kolejności przedstawiono teoretyczne podstawy stosowania kolaboracji $\mathrm{w}$ procesie edukacji tłumaczy, z uwzględnieniem korzyści, jakie potencjalnie niesie ona studentom studiów przekładoznawczych. Pod kątem praktyki, w oparciu o dotychczasowe badania własne, przedstawiono możliwe sposoby wywoływania refleksji w telekolaboracyjnych projektach thumaczeniowych realizowanych na poziomie uniwersyteckim oraz omówiono ideę wykorzystania konkordanserów jako narzędzia służącego pogłębianiu tejże refleksji. W podsumowaniu omówiono korzyści płynące z omawianego rozwiązania. 
Słowa kluczowe: telekolaboracja, konkordancje, refleksja, kompetencje miękkie

\section{SUMMARY}

This paper deals with the implementation of concordancers for the purpose of stimulating reflection on experience in telecollaborative translation projects at university level. The paper opens with a brief presentation of the rationale for the use of telecollaboration in contemporary translation and translator education. Then collaboration and telecollaboration are described as teaching/learning modes, with the latter presented as a computer-mediated extension of the former. Subsequently, the theoretical standing of collaboration in translator education is discussed, together with the learning gains that telecollaboration potentially offers to student translators. On a more practical note, on the basis of his own research conducted so far, the author presents means of eliciting reflection in telecollaborative translation projects administered at university level and introduces the idea of a concordancer as a tool for stimulating deepened reflection in such projects. The paper concludes with a summary of the benefits that concordancing brings to telecollaborative translation projects.

Key words: telecollaboration, concordancing, reflection, soft skills 